\title{
Thabo Mbeki, Postmodernism, and the Consequences
}

Robert Kowalenko

Quidquid agis, prudenter agas, et respice finem

\begin{abstract}
Explanations of former South African President Thabo Mbeki's public and private views on the aetiology of the HIV/AIDS epidemic in the country remain partial at best without the recognition that the latter presuppose and imply a postmodernist/postcolonialist philosophy of science that erases the line separating the political from the scientific. Evidence from Mbeki's public speeches, interviews, and private and anonymous writings suggests that it was postmodernist/postcolonialist theory that inspired him to doubt the "Western" scientific consensus on HIV/AIDS and to implement a public health policy that dragged its feet on full roll-out of antiretroviral therapy, causing thousands of avoidable deaths. A weak reductio ad absurdum allows us to conclude from this premise that postmodernist/postcolonial critique of "Western" science ought to be shunned. A comparative argument from consequences further suggests that in a situation where a misguided health policy has lead to a humanitarian catastrophe, and where postmodernist/postcolonialist critique of science can and has been used to justify this policy, an alternative theory ought to be preferred on which such justification would not be possible. The paper closes with a call for a non-relativist alternative to postmodernist/postcolonialist philosophy of science, and evaluates the potential of recent developments in "Studies of Expertise" to yield such.
\end{abstract}




\section{Introduction: the "South African HIV/AIDS Mystery"1}

South Africa is not the largest country in the world by population, by far. Yet in 2008 it was the country with the greatest number of people dying of HIV/AIDS, as well as the country with the greatest number of people living with it (310000 and 5.2 million, respectively). ${ }^{2}$ Other countries with comparable socio-economic development, GDP, and median income, such as Mexico and Brazil, posted much better numbers in the same period; African countries with significantly smaller health budgets, such as Uganda and Senegal, have also done better; ${ }^{3}$ and many African countries with comparable infection statistics, such as Swaziland, do not have comparable health budgets. Developed countries, finally, have succeeded to a much greater degree at controlling the epidemic and have reduced death and infection rates to comparatively small percentages. It is therefore fair to speak of a South African HIV/AIDS conundrum: the catastrophic dimensions of the epidemic here require explanation.

The conundrum deepens to a mystery when we consider the reaction to the epidemic of the South African government. Under President Thabo Mbeki (1999-2008), the government:

- made antiretroviral drugs (ARVs) freely available to HIV positive South Africans only in 2004, many years after poorer African countries did so, such as e.g. Namibia

- claimed that ARVs were toxic and that their efficacy was unproven

- restricted the use of freely donated nevirapine4 (an ARV drug)

- obstructed the access of South African entities to Global Fund to Fight AIDS grants (to buy ARVs) (Chigwedere, Seage et al. 2008: p. 410)

Furthermore, Mbeki in confidential letters and anonymously authored documents ${ }^{4}$ claimed that:

\footnotetext{
${ }^{1}$ I take this expression from the title of (Epstein 2000) and the subtitle of (Cullinan and Thom 2009).

${ }^{2}$ See (UNAIDS 2010: p. 185) and (HSRC 2009: p. 3); these numbers have improved somewhat in the latest official statistics.

${ }^{3}$ See e.g. references in (Nicoll and Killewo 2000).

${ }^{4}$ Principally, (Castro Hlongwane 2002) and (Ramatlhodi 2001); for background information on these see footnotes $n^{\circ} 6$ and $n^{\circ} 10$.
} 
- Western drug companies, governments, and scientists endorse the so-called 'consensus view' that AIDS is caused by HIV merely to promote the sale of ARVs in a political-commercial campaign for money and power (Castro Hlongwane 2002: Chapters II, XV, and passim)

- the "Western" scientific explanation of the high incidence of HIV infection in South Africa peddles centuries-old white racist beliefs that depict Africans as congenitally promiscuous and sexually rapacious (op.cit., Preface; also (Ramatlhodi 2001)).

- the scientific consensus view on HIV/AIDS 'is based on these racist beliefs and concepts, [and] makes a powerful contribution to the further entrenchment and popularisation of racism' and the dehumanisation of black people (Castro Hlongwane 2002: Chapter I).

Finally, Mbeki stated publicly that:

- HIV is but one of the causes of AIDS in Africa, if it is a cause at all; other, more important, causes are poverty, malnutrition, and other African diseases that pre-date AIDS, such as tuberculosis. E.g. (Mbeki 2000a); (Harvey 2000)

- a more comprehensive and adequate treatment response to AIDS in South Africa is therefore to fight poverty and malnutrition. (Mbeki 2000a)

An independent epidemiological study has estimated, conservatively, that as a result of the South African government's health policy 330000-343000 adult South Africans died preventable deaths in 2000-2005 (Chigwedere, Seage et al. 2008); see also (Nattrass 2008).

In Section 2 of this paper I shall argue that despite a deluge of research on this tragedy by scientists from multiple disciplines spanning the social and health sciences, Mbeki's public pronouncements on HIV/AIDS and his official health policy cannot be fully understood without taking due account of their philosophical underpinnings. I claim that Mbeki's explicitly stated views on the subject in fact presuppose and promulgate a recognisably postmodernist/ postcolonialist conception of science, corroborating this claim with excerpts from Mbeki's speeches and interviews, as well as privately and anonymously 
authored writings. Section 3 then draws a philosophical lesson from this in the form of two arguments, one a weak reductio ad absurdum, the other a comparative argument from consequences, to the effect that postmodernist/postcolonialist philosophy of science ought to be rejected, in favour of an alternative theory of science not susceptible to these arguments. The paper concludes with a brief and sceptical outlook on the potential of contemporary 'Studies of Expertise' to yield such an alternative.

\section{Mbeki hermeneutics}

The South African government's baffling position on HIV/AIDS-it is the only government in the world to at least temporarily have flirted with socalled 'AIDS denialism', the view that AIDS is not caused by HIV-in conjunction with the public health debacle in the country has prompted a large volume of research in multiple disciplines, including epidemiology, virology, political science, anthropology, sociology, economics, and history, as well as books by political activists, Mbeki biographers, and retired constitutional court justices. ${ }^{5}$ I shall not discuss the merits of this work here, but merely note that among the plethora of accounts, we can discern three different types of explanation of the government's stance:

- political/institutional as exemplified by (Butler 2005), (Lodge 2002); (Fourie and Meyer 2010); (Kauffman 2004); (Sheckels 2004); (Myburgh 2009); (Mulwo, Tomaselli et al. 2012)

- biographical/psychological (Kenyon 2009); (Gevisser 2007); (Gumede 2007)

- social/anthropological (Fassin 2007), (Phillips 2004), (Mbali 2004), (Youde 2005)

\footnotetext{
${ }^{5}$ See e.g. (Schneider and Fassin 2002); (Lodge 2002); (Mbali 2003, 2004); (Nattrass 2003, Nattrass 2007, 2008); (Sitze 2004); (Schuklenk 2004); (Kauffman 2004); (van der Vliet 1004); (Sheckels 2004); (Mosley 2004); (Butler 2005); (Youde 2005); (Cameron 2005); (Gevisser 2007); (Epstein 2007); (Gumede 2007); (Thornton 2008); (Chigwedere, Seage et al. 2008); (Kenyon 2009); (Kalichman 2009); (Cullinan and Thom 2009); (Chigwedere and Essex 2010); (Geffen 2010); (Fourie and Meyer 2010); (Mulwo, Tomaselli et al. 2012). This list is selective.
} 
These partially overlap, and the typology like most typologies is somewhat artificial. Yet, tellingly despite their different approaches each of the above authors accepts the necessity to answer to a basic question: were Mbeki's critics and political opponents correct to characterise his stance on AIDS as 'irrational', 'incompetent', 'marginal', 'paranoid', or 'bad, even evil'? (Dugger 2008); or could Mbeki, despite being factually wrong about the viral aetiology of AIDS, nevertheless be credited with uncovering an important truth that has the potential to partially or even fully justify his actions?

(Fassin 2007) typifies the social/anthropological answer to this question. He laments that 'the intellectual landscape of the AIDS epidemic has been reduced to simple terms' - on the one side, there is good sense and truth, medicine and science, and people of goodwill, on the other, there is incompetence and error, corrupt politicians and quack scientists - and that any sociologist or anthropologist who wants to explore things further "will be exposed to the doubly disqualifying accusation of denialist relativism and criminal irresponsibility' (op. cit.: p. 76). This damagingly simplistic dichotomy makes it hard to understand how a head of state who, by most accounts, is intelligent and honest, could have taken the "wrong" side; and even harder to understand why his views were, at the time at least, well received by large segments of the South African public (ibid.). Fassin cites (Lloyd 1990) and (Said 1978, 2003) to decry 'the hasty diagnostics of irrationality', in other words the tendency of Western scholars to scientifically "explain" as irrational those representations or acts by the non-Western 'Other' that they deem reprehensible or illegitimate (op. cit.: p. 77).

To avoid prejudice toward the Other as well as the nefarious "Western" assumption of a neat rational/irrational divide, 'a different reading of history and a different conception of politics' is necessary, says Fassin, a conception based on a 'historiography-informed ethnography' that includes an analysis of the ideological structure of the South African body politic, the colonial and Apartheid history of South Africa, Mbeki's personal experience, and the experience of black South Africans in the struggle against Apartheid generally (op.cit.: pp. xiv, 16ff). After all, South Africa has a long and deplorable track record of medical science being abused to justify oppressive interventions by white governments; and "Western" science, generally, a long history of giving 
legitimacy to some of the most deeply prejudiced theories about race. Fassin thus recommends a sociological interpretation of Mbeki's thinking on which the latter exhibits a 'particular rationality', an interpretation that would 'make biological and social theories of HIV/AIDS compatible with each other' (op.cit.: p: 15; my emphasis). For Fassin, Mbeki's politics and his social assumptions may have been quite correct; even though he may have been 'giving the wrong answers', he was 'asking the right questions' (op.cit: p. 99ff).

One of the central contentions of a private letter of 2001 by Mbeki to Malegapuru Makgoba is precisely that he (Mbeki) was justified to view the "Western" consensus on HIV/AIDS with suspicion, and to refuse to "leave science to the [western] scientists'. ${ }^{6}$ Mbeki attempts to persuade Makgobawho had been critical of the government's health policy - of his position on HIV/AIDS, and suggests that those who oppose him by asking the question

[...] what right does a non-scientist have, such as our President, to question matters that science in Britain, France, Portugal and the United States settled many years ago? (Ramatlhodi 2001: p. 4)

are in fact asking the question

[...] what right does any African have to question the findings of western science, regardless of whether or not he or she is a scientist or not! (ibid.; emphasis mine).

Mbeki enjoins Makgoba to join him in his fight 'against our slavish subservience to western science' (op. cit.: p. 5), and draws an analogy between the forced removal in 1901 of black Africans from Cape Town's District Six —on grounds of unsubstantiated claims that Africans disproportionately are carriers of the bubonic plague - and the HIV/AIDS hypothesis, according to which

${ }^{6}$ See (Ramatlhodi 2001). Professor Makgoba is a regarded immunologist who was President of the South African Medical Research Council at the time. The confidential letter, made public in (Dugger 2008), nominally is authored by Ngoako Ramatlhodi, Premier of the Limpopo Provincial Government during Mbeki's term (currently Minister of Mineral Resources). Yet Ramatlhodi was 'one of Mbeki's closest allies and his former speechwriter, and he often set out controversial views held by the president, but which he could not publicly express himself' (Gumede 2007: p. 330). Ramatlhodi himself has acknowledged that "his" 2001 letter to Makgoba was "drafted by Mr. Mbeki's Office' (Dugger 2008: p. A1). As in the case of (Castro Hlongwane 2002) there is little doubt that (Ramatlhodi 2001) accurately represents Mbeki's views on the science of HIV/AIDS. 
'once again, we the Natives are accused of being the biggest global threat to human life' (op. cit.: p. 11).

My aim here is neither to confirm nor to refute Fassin's social/anthropological or any of the other explanations of Mbeki's denialism in the literature; nor is it to attempt to supplant them with an explanation of my own, by uncovering, say, new facts about Mbeki's thought processes and the factors that influenced him; nor is it, of course, to refight the scientific battle against AIDS denialism, which long ago has been comprehensively won by medical science. ${ }^{7}$ It is, instead, to try to understand Mbeki's public pronouncements as well as his anonymous and private writings on the subject from the point of view of their most plausible philosophical underpinnings, in order to extract a philosophical argument from this episode of South African history. It turns out that many of Mbeki's pronouncements on the subject of HIV/AIDS and public health policy presuppose and imply a distinctly postmodernist/postcolonialist conception of science, as I will contend presently.

A few lexical comments are in order before we proceed, for the expression 'postmodernist/postcolonialist' needs elucidation. 'Postmodernism' and 'postcolonialism' are both elusive terms referring to a nebula of theories, practices and claims, and are difficult to define on their own, let alone in their relationship to each other. Postmodernism, we might say somewhat stipulatively, is characterised by a concern with: challenging the allegedly 'apodictic' or 'hegemonic' discourse of the modern age through adoption of an 'anti-systemic' mode of understanding that emphasises a plurality of perspectives and interfaces; with unravelling 'metanarratives' such as that of "scientific universalism" or European Enlightenment rationality; and with attacking overly economistic ways of interpreting social reality and culture. Postcolonialism on the other hand, is a critical practice concerned with the historical discourse and ideology of colonialism and European imperialism, as well as with the material, psychological and cultural effects on those subjugated to it; see (Quayson 2000: pp. 90-96). Insofar as postcolonialism 'bears witness to the unequal and uneven forces of cultural representation involved in the contest for political

${ }^{7}$ See e.g. (Cohen 1994); (O'Brien and Goedert 1996); (Chigwedere and Essex 2010); ("The Durban Declaration" 2000). Mbeki, by all appearances, mistook a risk factor (poverty) for a causative agent, see (Mosley 2004). For more on the aetiology of AIDS, see e.g. references n ${ }^{\circ}$ 3-7 of ("The Durban Declaration" 2000). 
and social authority within the modern world order' (Bhabha 1992), cited in (Quayson 2000: p. 94), it shares postmodernism's anti-systemic posture, and its desire to challenge the authority of hegemonic systems of representation that validate institutional subordination and silence marginal voices and experiences. Quayson, for one, thinks that postmodernism cannot explain the contemporary world without first becoming postcolonial, and vice versa (op. cit.: 106). While useful, these are very broad strokes, however. In Section 4 I shall adopt a much more circumscribed meaning for the term 'postmodernist/ postcolonialist' as applied specifically to the philosophy of science.

To show the postmodern/postcolonial soil from which Mbeki's pronouncements on science germinated, let's begin with his explicit view of science as political, pluralistic, and democratic. In a 2000 interview on the TV programme Carte Blanche, for example, Mbeki explains why he convened an Presidential Advisory Panel on HIV/AIDS composed in equal parts of representatives of the consensus position and of AIDS denialists, by stating that scientists must never suppress the voices of the minority. ${ }^{8}$ Science-like a pluralist democracy - must give everyone an equal right to be heard and, most of all, avoid being influenced by just one 'school of thought':

'I get the sense [...] that we've all of us been educated into one school of thought, and really I am not surprised at all that you would find, I'm quite sure an overwhelming majority of scientists in this field, in this culture, people would hold a particular point of view because that is all they were exposed to. This other point of view which is I think part of what is frightening, this alternative point of view, in a sense has been blacked out. It must not be heard, must not be seen, that's the demand now. Why is Thabo Mbeki talking to discredited scientists, giving them legitimacy. It's very worrying at this time in the world that any point of view should be prohibited, that's banned, there are heretics that should be burned at the stake. And it's all said in the name of science and health. It can't be right. (Mbeki 2000c)

(Jones 2002) comments that '[i]n presenting this as an issue concerning "freedom of thought and speech," Mbeki reveals that he sees Dissidents and Loyal-

8 Denialist scientists with genuine HIV/AIDS expertise probably never numbered more than a few dozen, while the 2000 Durban Declaration in support of the consensus position published in the journal Nature was signed by more than 5000 practising HIV/AIDS scientists. 
ists [adherents to the consensus view] as being on an equal epistemic level.' (op. cit.: p. 512). After all, suppression of the dissident position in public discourse could only be unjust if that position had as much epistemic right to be considered as the dominant position. It seems as if ' $[\mathrm{t}]$ here is nothing epistemically special, Mbeki thinks, about a scientific position being dominant. It is merely accepted by more scientists' (op. cit.: p. 513).

In (Castro Hlongwane 2002), Mbeki alleges that the global scientific consensus established 20 years ago that HIV causes AIDS

[...] was frozen at this particular moment into an unquestionable and unchangeable monument to scientific thought. Accordingly, further scientific inquiry into this matter is impermissible. Such scientific knowledge as was possible two decades ago must be supported by all and sundry, including scientists, as part of a religious dogma. (Castro Hlongwane 2002: Ch. I). ${ }^{9}$

In (Ramatlhodi 2001), Mbeki notes that 'almost by definition, new scientific truths are a repudiation of popular and generally accepted views, which makes scientific originality inherently an act of scientific rebellion', and suggests that their defenders must be protected. The 'rebels' and 'heretics' Mbeki is thinking of clearly are the AIDS denialists on his Advisory Panel (principally, Professor Peter Duesberg and Dr. David Rasnick). Mbeki describes his rationale for the Panel in these terms:

[Interviewer]: 'Some AIDS doctors say the evidence is overwhelming that AIDS exists and AZT [an early ARV drug] is of benefit. What is your comment on that?'

Thabo Mbeki: 'I say that why don't we bring all points of view. Sit around a table and discuss this evidence, and produce evidence as it

9 (Castro Hlongwane 2002), full title 'Castro Hlongwane, Caravans, Cats, Geese, Foot \& Mouth and Statistics: HIV/AIDS and the Struggle for the Humanisation of the African', is an anonymously authored discussion document distributed at the March 2002 National Executive Council meeting of the governing African National Congress (ANC). It was widely accepted at the time of its circulation to be President Mbeki's own work (an attributed co-author is Peter Mokaba; for discussion, see e.g. (Gevisser 2007: pp. 736ff)). There is consensus in the literature that it represents President Mbeki's considered position on HIV/AIDS, and that the latter is indeed "denialist." For a detailed defence of the view that Mbeki's health policy is attributable to his 'belief that several key tenets of science around AIDS are racist' and that 'denialism [is] a defence of Africans against racism and neo-imperialism,' see (Mbali 2004); also (Mulwo, Tomaselli et al. 2012). 
may be, and let's see what the outcome is, which is why we are having this International panel which we are all talking about. They may very well be correct, but I think if they are correct and they are convinced they are correct, it would be a good thing to demonstrate to those who are wrong, that they are wrong.' (Mbeki 2000c).

Even a reader superficially acquainted with scientific method will likely harbour misgivings about Mbeki's understanding of the scientific process as evinced here. Unlike in political negotiations - say, at a peace conferencescientific consensus is rarely established and opposing schools of thought rarely reconciled via round table discussions where parties either persuade their counterparts of the correctness of their view, or find "middle ground" through compromise and the reconciliation of competing interests. It is, rather, a gradual multi-year affair normally involving, among other things, a painstaking two-step peer review process of the available evidence by the scientific community; and it does not require acknowledgement of 'defeat' or even active participation in the process by the author(s) of the relevant theory. For it is in the nature of science that the latter will always have the theoretical or methodological wherewithal to avoid such acknowledgement if they wish, for example by 'cherry-picking' evidence — of which Duesberg and Rasnick have been accused; see (Cartwright 2010).

In fact, since every empirical test of a scientific hypothesis rests on an indefinite number of explicit as well as implicit background assumptions, it is possible to save any hypothesis - whether that be 'AIDS is not caused by HIV' or 'the Earth is flat' - from being falsified by the evidence through judicious adjustment of our assumptions regarding the evidence's reliability, relevance, etc.; see (Duhem 1906), (Quine 1951). By putting undue emphasis on conclusive evidence, or adopting an unreasonably strict standard of proof, it is possible to exploit the uncertainty inherent in all scientific knowledge in order to irrationally uphold any theory whatsoever. (This is exactly the strategy of global warming deniers and the Flat Earth Society). Scientific judgments usually are a matter of weighing the balance of probabilities, given the evidence, fairly appraised.

Of course, there is scope for attempting to read Mbeki charitably. Might he not simply be expressing the commonsensical methodological injunction that scientific research must remain "open-minded" when looking for a new 
hypothesis, trying to explain an anomaly, or trying to find a new cure? Moreover, is not the notion of a dominant school of thought, or paradigm, and its influence on the form and content of scientific research a staple of all post-Kuhnian philosophy of science? And is not gauging the precise extent to which subscribers to the dominant paradigm are obliged to engage scientific dissenters - as well as deciding what the tradeoff should be between the costs and risks of doing so and the value of epistemic pluralism - a very difficult exercise (Intemann and de Melo-Martín 2014)? Finally, is not the claim that Western science as practiced in the $20^{\text {th }}$ and $21^{\text {st }}$ centuries suffers from a democracy deficit a mainstay of contemporary sociology of science and science and technology studies (STS)? In other words, is Mbeki not on to a perfectly reasonable and legitimate criticism of extant HIV/AIDS science?

The problem is that Mbeki is not merely warning against the danger of clinging too strongly, in times of crisis, to an established paradigm; exhorting the virtues of epistemic pluralism; or calling for a better integration of science into the democratic decision process. Mbeki appears to literally model scientific dissent on political dissent. In his 'Letter to World Leaders', Mbeki attempts to explain the South African position on AIDS to the U.S. and various European governments, writing that a country like South Africa that has seen the face of tyranny has a moral duty to never allow tyranny to make a comeback. While the past tyranny was political, the present one in the context of the HIV/AIDS epidemic is that of a dominant scientific school of thought:

Not long ago, in our own country, people were killed, tortured, imprisoned and prohibited from being quoted in private and in public because the established authority believed that their views were dangerous and discredited. We are now being asked to do precisely the same thing that the racist apartheid tyranny we opposed did, because, it is said, there exists a scientific view that is supported by the majority, against which dissent is prohibited. (Mbeki 2000b), made public by (Gellman 2000)

Notice how Mbeki slides here from the oppression of political views to the oppression of scientific views. To him, it is 'precisely the same thing.'

The closing lines of (Castro Hlongwane 2002) in fine postcolonialist style quote the African-Brazilian Abdias do Nascimento to call on Africans to 
jettison the dogmas of 'scientific Eurocentrism', reject the notion of a 'definitive, universal truth', and carve out a space for an African one:

Black people require a scientific knowledge that allows them to formulate theoretically - in systematic and consistent form - their experience of almost five centuries of oppression, resistance, and creative struggle. [...] For centuries we have carried the burden of the crimes and falsities of 'scientific' Eurocentrism, its dogmas imposed upon our being as the brands of a definitive, 'universal' truth. Against this, we have, in struggle, made the statement to which we will remain loyal that we are human and African!' (Castro Hlongwane 2002: Ch. XV; Mbeki's emphasis).

In Mbeki's eyes, therefore, African politicians, far from being well-advised to leave science to the scientists, are morally bound to get involved: it would be 'a dereliction of duty if we were to say, as far as health issues are concerned, we will leave it to doctors and scientists' (Mbeki 2000c). Mbeki seems genuinely to believe that science and politics are joined at the hip: science is not separate and cannot separate itself from the social-political sphere, and the truths it delivers cannot and must not be separated from their social-political determinants; if one is justified in rejecting those social-political determinants - such as, in the case of "Western" medical science, colonialist and Apartheid ideology - then one is justified to reject its truths.

Thus, Mbeki argues in his Letter that mass distribution of ARVs is not an appropriate public health response to the epidemic in Africa, because 'a simple superimposition of Western experience on African reality would be absurd and illogical'. The chief difference between 'Western experience' and 'African reality' are disparities in HIV/AIDS propagation characteristics: 'unlike in the West, AIDS in Africa is heterosexually transmitted, it kills millions here whereas it kills thousands there, and deaths are increasing, rather than decreasing' Mbeki 2000b. Another important characteristic Mbeki does not mention is HIV prevalence by population group; in South Africa in 2008, it was: African $13.6 \%$, Colored $1.7 \%$, White $0.3 \%$, Indian $0.3 \%$, tracking both traditional race categories and socio-economic status; see (HSRC 2009). (Fassin 2007) suggests that Mbeki's intention in his Letter to World Leaders is merely to 'understand the specificities of the African epidemic and [to] choose solutions adapted to that context' (op.cit.: p. 6). But (Castro Hlongwane 2002) 
makes it abundantly clear that Mbeki fears that these statistics feed into a racist narrative of black Africans being selectively decimated by a virus because of their sexual and moral depravity, and that this narrative is the very foundation of the "Western" HIV/AIDS hypothesis itself (mirroring early homophobic "explanations" for HIV/AIDS propagation characteristics in the West in the 80 s and 90 s). ${ }^{10}$ If the narrative is wrong, so must be the hypothesis.

(Castro Hlongwane 2002) also makes it clear that Mbeki's rejection of the "Western" treatment response to HIV/AIDS cannot not be understood as merely an isolated instance of an African leader rejecting a specific recommendation issued by a "Western" science and pharmaceutical industry he perceives as exploitative and racist. The text is permeated with calls for the liberation of Africans from centuries of oppression, for the recovery of their dignity, and their intellectual and psychological emancipation from the [Western] 'omnipotent apparatus' (a specious concept Mbeki borrows from (Marcuse 1955)). In fact, Mbeki around the same period elaborated one of the cultural policies he is most known for: his call for an 'African Renaissance', a broad transformative change that consists, as he put it in an address to a conference of African universities, in 'the economic, social, cultural and political renaissance of [the African] continent and in the drive for the development of Indigenous Knowledge Systems (IKS)’ (Mbeki 2005).

A crucial part of the African Renaissance, according to Mbeki, is that 'all critical and transformative educators in Africa embrace an indigenous African world-view and root their nation's education paradigms in an indigenous socio-cultural and epistemological framework' (ibid.). African educational curricula, in particular, should be indigenous-grounded and orientated, Mbeki argues, failing which they would remain alien and irrelevant to African society, 'as is seen to be the case with the legacy of colonial and neo-colonial education systems' (ibid.). The fundamental reorientation required by the African renaissance requires, furthermore, that African universities assume ' $[\mathrm{a}] \mathrm{n}$

\footnotetext{
${ }^{10}$ For a good explanation of the African data that is neither absurd and illogical, nor racist, yet perfectly "Western", see e.g. (Epstein 2007: pp. 49-66); cf. however, (A1lais and Venter 2012: pp. 401-404) for an objection to her argument. For a closely analogous example by Bruno Latour of 'excessive distrust of good matters of fact disguised as bad ideological biases' (i.e. global warming denialism in the U.S.), see (Latour 2004: p. 227).
} 
African identity and vision that $[. .$.$] represents a critical point of departure$ from the current colonial-Western identity which is neither suitable nor compatible with this identity.' It should create, in particular, '[...] a new paradigm that locates the African condition, knowledge, experiences, values, world-view and mindset at the centre of our scholarship and knowledge-seeking approach' (ibid.). In other words, Africa needs 'a distinctively African knowledge system' (ibid.). Mbeki's call for an African Renaissance was widely acclaimed as 'a call for African pride, African sovereignty, a 're-birth' of African self reliance', and has been influential throughout the African continent (Thornton 2008: p. 132).

Yet, insofar as it aims to complete the process of decolonisation via the rejection of a "Western" epistemological framework, the African Renaissance would appear to aim at rehabilitating an African IKS and epistemology that is standardly thought to include supernatural and 'paranormal' paths to knowledge; (Asante 2005: 40), cited in (Horsthemke 2010: 30-31). For, African epistemology, according to Asante, comprises special methods of "knowing" such as divination and revelation, extrasensory perception, and the communication with supernatural beings such as spirits and ancestors imparting knowledge through 'mediums, diviners, animals, extraordinary life events, or natural phenomena' (ibid.). (Dei 2004) explains that affirming 'African ways to know' means affirming 'that personal subjectivity and emotionality must be legitimised, [t]hereby asserting that the [Western] subjectivity/objectivity and rationality/irrationality splits are false' (op.cit: p. 340), cited in (Horsthemke 2010: p. 31). African IKS are not merely claimed to be epistemically legitimate; an outsider's judgment that the knowledge claims of an IKS are untrue or lacking adequate justification is said to constitute 'epistemic injustice' and to be tantamount to inflicting 'epistemic harm' (Horsthemke 2010: p. 30)harm of the type historically inflicted by colonial and Apartheid regimes.

Mbeki's call for 'a distinctively African knowledge system' will resonate with readers familiar with postcolonial STS. They will recognise, in particular, his criticism of "Western" science's pretensions to universality, its dominating, exploitative, imperialist, and racist character. In STS the "Western" sciences have long been viewed as "just one kind of culturally specific "ethnoscience" among the many that have existed' (Harding 1992: p. 311), and authors in this 
field have long called for the development and strengthening for contemporary purposes of non-Western scientific traditions that respect the cultural legacies of postcolonial societies. The Mbeki of (Castro Hlongwane 2002) and (Ramatlhodi 2001) thus would probably find himself well represented by Harding's description of postcolonial STS as engaged in the criticism of not just the technologies, applications, and social institutions of "Western" science, but also of its very technical/cognitive core, as harbouring 'distinctive and unattractive cultural and political commitments' (ibid.). 'These critics', Harding writes, 'are opposed not to science, but to the world-wide dominance of only one ethnoscience, and of one that inherently legitimates-perhaps even requires - an imperialism against other scientific traditions, other cultures, other peoples and nature itself' (ibid.)

Whether and to which extent Mbeki was opposed to "Western" science in this way is neither entirely clear, nor uncontroversial, however. Did he really intend the African Renaissance to lead to the revival and legitimisation - at the expense of "Western" science — of an African Epistemology and IKS that would include traditional magical thinking and the supernatural? (This is the neo-traditionalist or 'strong Afro-centrist' interpretation of the African Renaissance project). In public, he much more frequently vaunted other expected benefits, such as democratisation, poverty reduction and accelerated economic growth through liberal policies such as NEPAD. (This is the 'modernistic' interpretation). Moreover, Mbeki generally does not appear to display much epistemological suspicion against "Western" science in fields other than medicine, such as economic policy, technology, etc. ${ }^{11}$ According to this line of thought, to explain South Africa's AIDS policy tragedy we should instead single out as the primary factor the personal influence on Mbeki of the (perfectly Western) AIDS denialists; see e.g. (Schuklenk 2004), (Weinel 2007). AIDS denialism, after all, is a world-wide phenomenon and perhaps South Africa's misfortune was simply to have been saddled with a post-apartheid president who happened to get personally sucked into the denialist community, as have many others at the time (Nattrass 2011). But this does not explain why no other government leaders-who, especially in English speaking countries, were equally exposed to public campaigns waged by the 'dissidents' in feature

${ }^{11}$ As pointed out to me by Nicoli Nattrass (personal communication). 
length TV programmes, newspapers articles, websites, etc.- took the bait, while Mbeki swallowed it hook, line, and sinker.

I submit that Mbeki could have fallen for denialism, because his postmodernist/postcolonialist belief system - among the pillars of which are the 'debunking' of the universalist truth-claims of "Western" science, the denial of its presumed monopoly on scientific knowledge production, and the unravelling of its socio-economic, historical, and ideological determinants-predisposes to this. ${ }^{12}$ (Mbeki 2005), (Ramatlhodi 2001), and (Castro Hlongwane 2002) certainly provide evidence that Mbeki when speaking privately and anonymously as well as publicly is very much prone to using the language of postmodernism/postcolonialism, e.g. when he expounds his view that a genuinely "African" science based on non-Western ideological and cultural determinants should have non-Western scientific content, as well. And he certainly uses postmodernist/postcolonialist concepts, such as that of the 'omnipotent apparatus', to justify his positions. Note, however, that while I wish to claim here that postmodernist/postcolonialist theory generally predisposes to denialism, I hesitate to maintain that Thabo Mbeki himself did fall for it because of his postmodernism/postcolonialism. To do so would be going beyond the available evidence, and in any event, incidental to the philosophical argument to be made in the next section.

To wrap up our South African case study: Mbeki's desire to free Africa from the cultural, political and economic subjugation of the West took in the case of the HIV/AIDS epidemic the form of his government merging the search for an idiosyncratically African remedy (e.g. the failed miracle cure $\mathrm{Vi}$ rodene, see Myburgh 2009) with advocacy for African Traditional Medicine, and a now infamous public health response that sought to complement ARV distribution programs with an emphasis on poverty reduction and improving nutrition through garlic, lemon, beetroot, and the South African potato; see (Butler 2005), (Thornton 2008: pp. 133-34). Only a Cabinet revolt in 2003-

12 As implicitly acknowledged by (Weinel 2007: pp. 757-58); see also (Lodge 2002), (Sheckels 2004). For more on how postmodernism has fuelled various conspiracy theories and denials of bona fide scientific facts, see (Latour 2004), and infra. 
brought about in part by successful legal challenges, ${ }^{13}$ political pressure from opposition and civil society groups, international ridicule, and ministers' growing concern for damage to the reputation of the country as an investment opportunity - followed by Mbeki's ultimate ouster from office in 2008 allowed for a gradual policy reversal and implementation of scaled up ARV distribution programs.

In 2012, ARV treatment coverage in South Africa reached 83\% under WHO 2010 guidelines to provide access to ARVs for every South African citizen with a CD4+ T lymphocyte count of $<350$ cells $/ \mathrm{mm}^{3}$ (UNAIDS 2012). AIDS related deaths in South Africa are estimated to have fallen to 194,000 in 2010 ASSA 2011, and life expectancy for those who do start antiretroviral therapy has returned to near-normal pre HIV/AIDS levels (Johnson, Mossong et al. 2013).

\section{3. "Epistemic charity" and the consequences}

Recent South African history illustrates that it is not without real world consequence which philosophy of science health policy makers subscribe to. In a paper read to the 20 $0^{\text {th }}$ World Congress of Philosophy, Daniel Dennett argued that the cluster of theories called 'postmodernism' has spawned a meme (a replicating idea) that has spread around the world like a virus, with devastating consequences, in particular for the developing world (Dennett 2000); see also (Dennett 1997). The meme in question is the idea that "Western" science was a colonial imposition on the developing world, not at all a worthy substitute for the traditional science and the traditional practices and beliefs it attempted to replace. "Western" science, according to this meme, is but one among many equally valid narratives, and not to be privileged in its competition with native traditions (op. cit.: p. 94). This "virus" had dire effects, claims Dennett:

${ }^{13} \mathrm{HIV}$ infection dramatically increases child mortality and is a significant risk factor for cerebral palsy and other debilitating diseases. The Mbeki government refused to provide zero positive women in labour with highly effective prophylactic ARV treatment and threatened doctors found administering it with disciplinary action or dismissal. It was compelled to relent in 2002 by a high-profile Constitutional Court case, which ultimately reduced the mother-to-child transmission rate from up to $35 \%$ in 2000 to less than $4 \%$ in 2012, and is saving the lives today of approximately 70000 children per year; see (de Cock, Fowler et al. 2000). 
[...] it raised infant mortality rates, led to a general decline in the health and wellbeing of women and children, and, perhaps worst of all, indirectly [strengthened] the hand of the traditional despot who ruled the nation (Dennett 2000: p. 93).

Dennett 2000 does not attempt to substantiate these specific claims, referring us instead to work in STS by (Nanda 1998), (Afshari 1994), (Okin 1997), and (Hoodbhoy 1991) (on India, Pakistan, women, and Islam, respectively). (Nanda 1998), for example, studied popular resistance in 1970s rural India to smallpox vaccination campaigns based on the modern cowpox-based vaccine. She notes that some Western anthropologists and Indian scientists defended the resistance at the time on the grounds that the vaccination campaign amounted to an "imposition of "Western logocentric mode of thought". The latter distinguishes, in a distinctly un-Indian way, between natural and supernatural forces and thereby constitutes an affront to the (much more dangerous) local custom of inoculation with human smallpox, 'accompanied by prayers to the goddess of smallpox, Sitala Devi' (op.cit.: p. 289ff) (Despite this, India announced complete eradication of smallpox in 1977, thanks in large measure to the cowpox-based vaccine).

Like Dennett, Nanda notes that there is a cluster of theories of science that

[...] forbids outsiders from evaluating the truth or falsity of any beliefs of other people in other cultures from the vantage point of what is scientifically known about the world and, conversely, allows the insiders to reject as ethnocentric and imperialistic any truth claim that does not use locally accepted metaphysical categories and rules of justification. (Nanda 1998: p. 286), see also (Nanda 2003).

Nanda argues that theories in this cluster effectively dispense a form of epistemic charity, an epistemic "gift" given by well-meaning, mostly Western, theorists to the formerly oppressed. To be 'epistemically charitable' is to hold that

[...] because modern "Western" science is but one among the many ways of understanding the world and is as embedded in its own cultural context of production as other knowledges are in theirs, it cannot serve as a transculturally valid source of knowledge. All sciences are ethnosciences, and none is more universally true than any other. This 
gift has many names, many givers, and many presumed beneficiaries.' (ibid.)

The developing world, Nanda suggests, should 'respectfully return the gift'.

Nanda's and Dennett's position may have received support from unexpected quarters. The French critical theorist and sociologist of science Bruno Latour describes the "terrible irony" that postmodern theory has taught for years that

'[...] behind the appearance of objective statements hide real prejudices, that facts are made up, that there is no such thing as natural, unmediated, unbiased access to truth, that we are always prisoners of language, that we always speak from a particular standpoint, and so on, while dangerous extremists are using the very same argument of social construction to destroy hard-won evidence that could save our lives.' (Latour 2004: p. 227).

The 'dangerous extremists' Latour is referring to are conservative U.S. politicians who deny climate change by intentionally exploiting and emphasising the lack of absolute scientific certainty for their political goals. Latour also mentions the New York 9/11 terror attack conspiracy theorists and those who deny that man ever landed on the moon, as being in the same group of people; clearly, he could have added AIDS denialists to this list.

What all these denialisms have in common, according to Latour, is that they use exactly the same patterns of argument and explanation: they develop a social critique that encourages us to be sceptical of what scientists say, because they are either dishonest or unaware of their real motives; they then offer an explanation in terms of powerful agents, hidden forces, shady and greedy groups at international pharmaceutical companies, or more generally, society, discourse, knowledge/power, capitalism, or colonialist empires (ibid.). Similarly to Dennett, Latour worries that STS theorists, like mad scientists, may have let the "virus" of postmodern critique out of their laboratories, and are now powerless to do anything to limit its disastrous effects (op.cit.: p. $230-231) .{ }^{14}$

I will follow Nanda and henceforth refer to those authors and theories of science that could fairly be described as 'epistemically charitable' —or as dis-

\footnotetext{
${ }^{14}$ Latour somewhat dials back this criticism in the latter parts of his article.
} 
pensing the "gift" of epistemic charity as defined above-collectively as 'postmodernist/postcolonialist' (often abbreviated to 'postmodernist'). One of the postmodernist givers, according to Dennett, is the philosopher Richard Rorty (op.cit.: p. 97ff); numerous contemporary sociologists of science, STS theorists, anthropologists, postcolonial and critical theorists, probably are as well. Thabo Mbeki, insofar as he did not actively participate in the development of postmodernist theory or 'epistemic charity', but rather used postmodernist arguments to justify his public health policy, would be a beneficiary.

What philosophical lesson, then, can we learn about postmodernism and epistemic charity from the HIV/AIDS tragedy in South Africa? It would be tempting to argue as follows:

(i) Postmodernist critique relativises "Western" science as but one among many narratives without epistemic authority over the truthclaims of "non-Western" sciences and knowledge systems. (Premise)

(ii) The one-time President of South Africa, Thabo Mbeki, was prompted by postmodernist critique to doubt the "Western" scientific consensus that HIV causes AIDS and to implement a health policy that delayed widespread implementation of ARV-drug distribution programs to combat HIV. (Premise)

(iii) The delay in implementation led to the avoidable AIDS deaths of hundreds of thousands of people. (Premise)

(iv) Thabo Mbeki was prompted by postmodernist critique to implement a health policy that lead to the death of hundreds of thousands of people. (from ii, iii)

(v) Any theory of science which is apt to contribute to grave realworld consequences such as these should be rejected. (Premise)

(vi) Postmodernist critique of "Western" science is such a theory. (from i, ii, iii)

(vii) Therefore, postmodernist critique of "Western" science should be rejected. (from v, vi)

But there are several obvious problems with this. First, premise (ii) has been motivated in Section 2, but certainly not conclusively established. The argument is only as likely to be sound as the empirical claim in (ii) is likely to be true. Worse, if its intended upshot is the falsity of postmodernist critique of science, then it amounts to an argument from adverse consequences, which is 
logically invalid: "If postmodernist critique is true (or believed to be true), then consequence $\mathrm{X}$ ensues. $\mathrm{X}$ is morally undesirable. Therefore, postmodernist critique is false" is a non sequitur. (Maffie 2005: p. 69-70) attributes a fallacy of precisely this kind to Nanda. Of course, technically postmodernism's falsity is not the intended upshot of the argument, since the conclusion states simply that postmodernist critique of science ought to be rejected, which we can interpret as meaning that it should not be endorsed, publicly approved, or supported. (A suppressed premise here being that outcomes such as preventable deaths are undesirable for moral reasons, and that anything, including endorsement of a theory, that contributes to such outcomes ought to be avoided for those moral reasons). Note that arguments from consequences of this or a similar kind do have a standard use in pragmatics, ethics, and public policy. Moreover, since the relation between the theory and the outcomes may have been unforeseen and certainly unintended, the argument would not license moral judgement of the author(s) of postmodernism; cf. (Maffie 2005).

Even so, there is something unsatisfactory about the dialectical situation created by such an argument. (Edwards, Ashmore et al. 1995) note that arguments against epistemological relativism often involve either furniture (as in: "but, surely, this table is real?"), or death (as in: "relativism actually produces death and misery, genocide, poverty," etc.). The general form of 'bottom line' arguments like the above is always the same, they say: there is a reality which relativists deny, and by denying it, refuse to oppose, which will ultimately assert itself in an act of terror or poetic justice-i.e. it will kill us for our (allegedly) false representations of the world (op. cit.: p. 34). Edwards et al. think that it is easy to turn the tables on this kind of argument. For the idea that only realist, i.e. non-relativist, thought can 'bar the gate to the polis and keep the night, the jungle and the jackals at bay', (Smith 1988: p. 154), cited in (Edwards, Ashmore et al. 1995: p. 33), is mistaken. Death and misery, genocide, poverty, happen anyway - and they certainly have happened during the period of realism's dominance when science was complicit with colonialism, imperialism, racism, sexism, homophobia, etc. As they put it, realism is

[...] no more secure than relativism in making sure the good guys win, nor even of defining who the good guys are [...]. Realists cannot claim 
the political and moral high ground. (Edwards, Ashmore et al. 1995: p. 35).

Their objection, then, is a tu quoque: "Modernism kills, too..!" Indeed, an important theoretical aim of STS and postcolonial studies in the 20th century has been to uncover and document the many harms caused by "Western" science's universalist pretensions, its historical complicity with and active contribution to imperialism, racism, sexism, homophobia, and other ills. But $t u$ quoque rejoinders are of course fallacies, too: even if it can be shown that 'realist' theories of science have also had negative real-life effects on the developing world, women, black people, and other marginalised groups, then this would still be irrelevant for the point I have made about the connection between postmodernist critique of science, Thabo Mbeki's AIDS denialism, and the South African humanitarian catastrophe. Moreover, while the tu quoque objection counters one argument from consequences with another, it fails to account for the intuition that there is a difference between the use for morally questionable aims of a true theory (e.g. when parts of "Western" science are co-opted for the aims of empire, capital, patriarchy, etc.), and the use for morally unquestionable aims of a false theory (as, presumably, in the case of Mbeki's embrace of denialism in the aim of furthering public health and African nation building). For one, the adverse consequences in each case are potentially of a different kind, which we could chalk up to the immoral nature of the aims in the former case, and to the falsity of the theory in the latter.

Precisely assessing the force and limits of arguments from adverse consequences is certainly difficult. (Jansen 2007) suggests that arguments from consequences are not clearly distinguishable from what she calls a 'weak reductio ad absurdum'. 'Strong reductios' are arguments of the form 'If X, then Y. Y is absurd. Therefore, not-X', where $\mathrm{Y}$ is thought to be absurd because it is either internally inconsistent, or inconsistent with $\mathrm{X}$. A weak reductio, by contrast, appeals merely to the strong implausibility of the consequent of the conditional premise; for different nomenclatures, see (Kneale and Kneale 1962: p. 9) and (Rescher 2005), cited in (Jansen 2007: p. 252). A weak reductio is thus only as strong as the perceived degree of implausibility, and according to Jansen it is not clearly distinguishable from arguments from adverse consequences: like the latter, a weak reductio can express causal rela- 
tionships and have normative conclusions, i.e. it can appeal to consequences that contradict generally held opinions about values and norms, and that as a result are perceived as "absurd", because they are extremely undesirable (op. cit.: p. 259). Thus, we might say that (i)-(vii) is actually a weak reductio: it depicts consequences (avoidable deaths) that are not just undesirable, but absurdly so (ibid.).

While interpreting (i)-(vii) in the above way as a weak reductio might allow us to draw a somewhat mitigated conclusion regarding the truth of postmodernist critique of science, another form of argument suggests itself that avoids overselling the conclusion, eschews difficult to establish claims about Thabo Mbeki's thought processes, and preempts the tu quoque response of the postmodernists, as follows:

(1) Postmodernist critique relativises "Western" science as one among many narratives without epistemic authority over the truth-claims of "non-Western" sciences and knowledge systems. (Premise)

(2) Postmodernist critique* does not relativise "Western" science as one among many narratives without epistemic authority over the truth-claims of "non-Western" sciences and knowledge systems. (Premise)

(3) The President of South Africa, Thabo Mbeki, doubted the "Western" scientific consensus view that ARV-drugs are effective in combating HIV/AIDS, and implemented a health policy that delayed widespread distribution of ARVs. (Premise)

(4) The delay in distribution of ARV-drugs led to the avoidable AIDS deaths of hundreds of thousands of people. (Premise)

(5) In virtue of the fact that postmodernist critique relativises "Western" science, it could naturally be appealed to in justifying a health policy response that led to an avoidable humanitarian catastrophe (from 1, 3, 4)

(6) In virtue of the fact that postmodernist critique* does not relativise "Western" science, it could not easily be appealed to in justifying a health policy response that led to an avoidable humanitarian catastrophe (from 2, 3, 4)

(7) (5) and (6) provide a strong reason for preferring postmodernist critique* over postmodernist critique. (Premise) 
(8) Therefore, postmodernist critique* should be preferred over postmodernist critique. (from 7) ${ }^{15}$

Here, (3) can easily be textually corroborated. (4), similarly, is a scientifically well-established fact, whereas premises (1) and (2), while definitional can be shown to be satisfied by various accounts of science in STS and contemporary sociology of science; see (Koertge 1998). (5), independently plausible as it is, has been illustrated in Section 2 by means of Mbeki's private and anonymous writings, as well as being endorsed by Dennett, Nanda, and Latour. A further advantage of the argument is that it avoids a shoot-out with Edwards et al. over which philosophy of science historically has more blood on its hands. For to the extent that (7) is true and independently of what else is true, it undoubtedly provides pragmatic grounds for shunning postmodernist critique, and the genocidal dimensions of the health crisis suggest that these grounds are very strong. Moreover, since the argument contrasts a brand of postmodernist theory that relativises "Western" science and that can and has been used to justify misguided public policy, with an unspecified alternative which does not, it simply calls for a non-relativist alternative to mainstream postmodernist theory that cannot be so used - not necessarily for a a return to modernism. This alternative non-relativist philosophers have so far been slow to provide.

This is not to say that attempts are not afoot. Harry Collins, Robert Evans, and Martin Weinel from the University of Cardiff, for example, are calling for a 'Third Wave' in STS, inaugurated by what they call 'Studies of Expertise and Experience'; see (Collins and Evans 2007), (Collins 2007), (Collins, Weinel et al. 2010). This new type of STS would, on the one hand, safeguard the presumptive theoretical and epistemic advances made by social constructivism and 20th century sociology of science - namely the discovery that, as Latour put it so succinctly, 'prejudices hide behind apparently objective statements, that facts are made up, that there is no such thing as unmediated access to truth, that we always speak from a particular standpoint'; and on the other hand, it would recognise that the democratisation of technical deci-

${ }^{15}$ My thanks go to Mikkel Gerken who first suggested a comparative form of the argument to me. 
sion-making processes does not, as many postmodernists/postcolonialists appear naively to believe, always lead to more socially and morally desirable outcomes.

A key notion of Third Wave Science Studies so defined is the notion of 'expertise'. Collins and Evans propose a classification of expertise into five different types, whereby Mbeki would only have had an intermediary kind of expertise, 'primary source knowledge' (PSK), the highest form being 'interactional/contributory expertise'; (Collins and Evans 2007: p. 14), (Weinel 2007: p. 755). PSK does not involve specialist knowledge, whether tacitly or explicitly, and can be acquired by merely reading published scientific papers without any social or professional contact with interactional/contributory experts in a particular field. (Weinel 2007: p. 758) argues that because Mbeki did not have the highest form of expertise, he ought to have given special weight to the advice of genuine interactional/contributory experts - such as Makgoba or Luc Montagnier, co-discoverer of HIV and member of the Presidential Advisory board - in respect of the technical dimensions of HIV/AIDS health policy. While the conclusion may be correct, Weinel unfortunately fails to address the obvious retort that Mbeki did appear to have given "special weight" to the advice of genuine interactional/contributory experts. But, tragically, they were the wrong ones (namely, Duesberg and Rasnick).

(Jones 2002), who studies precisely the question 'Which scientists should we trust?' argues that a representative of the scientific consensus is, ceteris paribus, less likely to take an epistemically biased stance on a particular scientific question, than a scientific dissident. Therefore policy makerswho are unable to evaluate the issues themselves, because they lack sufficient expertise - need to make a bet on the dominant scientific community being right rather than the dissidents. Jones' reasons for believing that a theory accepted by the majority of the scientific community is less likely to be biased are that (a) the scientific community considers scientific claims solely based on their evidence (in other words, the publicly endorsed considerations in favour of acceptance of a scientific claim are always exclusively epistemic, or truth-seeking); and (b) communal acceptance of a claim is always dependent on the absence of counter-evidence, and on no counter-claims being made in the community. Thus, Jones suggests that the discursive and public nature of 
science ensures that scientific beliefs are both 'evidence-determined' and 'evidence-sensitive'; and that scientific consensus represents our best bulwark against epistemic bias, and our best chance for gaining the truth about a matter. By contrast, we cannot be as assured, in principle, that an individual dissident scientists' acceptance of a theory is equally truth-oriented, and that his/ her epistemic commitments are not the result of personal bias (Jones 2002: p. 520).

While admirable in its intent and, possibly, as a normative ideal for the collective practice of science, a weakness of the argument in (Jones 2002) is that it does not provide a justification for Jones' apparent confidence in the non-existence or irrelevance of inter-subjective and community-wide causes of epistemic bias. As such, his analysis appears to disregard 40 years' worth of work in STS and the sociology of science. Some of a scientist's motivations and reasons for theory acceptance can be systemic and institutional, and yet quite opaque to him/herself as well as to the entire community of which she is a member. How else to explain past scientific theories that are blatantly biased and yet once enjoyed community-wide acceptance? One of the signature claims of, say, Sandra Harding's 'Standpoint Epistemology' is precisely that marginalised outsiders can occupy epistemically privileged positions, because they do not share the dominant scientific community's ideological, political and moral beliefs and value system. Be that as it may, (Jones 2002)'s analysis fails to provide us with the tools for understanding Mbeki's choice to lend his ear to one set of scientific experts, who defended a position ostensibly more congenial to his political and ideological outlook, rather than to another.

Collins, Evans, and Weinel's work appears promising due to its admission that in modern democratic societies the public and its representatives must, after all, allow science-more precisely, the right kind of scientific expert - special epistemic authority with respect to certain questions. It certainly has considerably rocked the boat in STS, going against the grain of much of the relativist science 'debunking' literature of the 1980s and 90s. Collins, Evans, and Weinel recognise that scientific values and a special epistemic status accorded to subject experts must be a key part of a democratic cum scientific society; they call this position 'elective modernism'. Their theory of expertise is detailed and prima facie quite powerful - the conjunction of their's and 
Jones' criterion certainly seems to rule out AIDS denialists as acceptable sources of epistemic authority in the South African Case. Yet, Studies in Expertise and Experience are still a new field, and even though it is highly plausible that there are indeed distinct levels of expertise, I am not convinced the case has been successfully made that it is possible to make the correct qualitative judgments regarding expertise without availing oneself of the one category or scientific value that even Collins and Evans do not want to talk about: truth.

What makes someone a top-level expert is not just that they make contributions in their field, have interactional/contributory as well as social relationships with a group of other such experts, and participate in this group's practices (Collins and Evans 2007). A top-level expert also knows certain central truths about the relevant field, or perhaps more truths than a non-expert or lower-level expert. For a person who knows few such truths or no truths at all about X could hardly appropriately be called an 'expert' about X, even though she might de facto be referred to as such in various social or historical contexts. Even an entire group of such people would still not be proper experts, although they might interact and engage in different manners of expertlike practices. Renaissance doctors, for instance, despite being considered and referred to as medical "experts" during their time and engaging in expert-like behaviour, were not, simply in virtue of having too many false beliefs about the human organism. Finally, a person who knows significantly more central truths about $\mathrm{X}$ than another would have reason to call herself a better expert on this ground alone. (There are, of course, further factors in expertise, such as tacit knowledge and skill).

Given the central role Third Wave Science Studies attribute to experts in a democratic society, this is not merely a Humpty-Dumpty type of disagreement regarding the correct meaning of the word 'expert'. An account such as that offered by Collins and Evans still seems to offer too few epistemic constraints on expertise to be recognisably non-relativist, or truth-centred. Insofar as this is the case, their 'elective modernism' threatens to collapse back into familiar postmodernism; and the alternative 'postmodernist critique*' to continue to elude us. 


\section{Conclusion}

South Africa continues to carry an extremely high disease burden and at the time of writing is still home to approximately 6 million people living with HIV/AIDS. While the likely causes for this debacle are many, health policy failure is undoubtedly one of them. President Thabo Mbeki's near-inexplicable resistance in the 1999-2003 period to ARV drug distribution programmes as recommended to him by WHO, UNAIDS, and most local South African medical experts, black and white, has been the object of many theories and explanatory sketches. Many of these appeal to history, identity, politics, ideology, and personal psychology. Gevisser's excellent biography is especially compelling when it describes Mbeki as "the National Interferer", a man displaying the character trait of a certain frustration at the incompetence of his comrades coupled with the self-confidence of being assured of his own competence, and the belief that 'if you want something done, you have to do it yourself' (Gevisser 2007: p. 426). Other works in the nascent genre of Mbeki hermeneutics offer similarly interesting insights into the South African HIV/AIDS mystery.

Yet, all of these explanations must remain partial, I have argued, without the recognition that Mbeki's views on HIV/AIDS presuppose a philosophy of science that erases the line separating the political from the scientific. The feminist philosopher of science Helen Longino wrote that a feminist science and epistemology requires scientists consciously to choose those background assumptions and explanatory models that are congruent with their political values; and that feminist scientific practice 'admits political considerations as relevant constraints on reasoning, which through their influence on reasoning and interpretation shape content', the ultimate goal being to 'prevent the erasure from inquiry of a gradient of power that keeps women in a position of subordination' (Longino 1994: p. 481). Exactly the same can be said, mutatis mutandis, of postcolonial philosophy of science, and of Mbeki's conscious choice of an explanatory model of the HIV/AIDS epidemic that accommodates his political values as head of the new South African state and the goals of the African Renaissance.

I thus advanced a first argument that lays the blame for the health crisis at the feet of postmodernist/postcolonialist doubt about "Western" science, via the premise that it was this doubt that moved Mbeki to implement a health po- 
licy that dragged its feet on roll-out of antiretroviral therapy; and I concluded that postmodernist critique of "Western" science ought to be shunned. But while plausible given the textual evidence, it is difficult to conclusively establish the premise, and the truth-relevance of the conclusion depends on one's view on the dialectic force of 'weak' reductios ad absurdum. Yet, truth - in our case, the truth that HIV causes AIDS - still matters. Postmodern anthropologists, social epistemologists, and critical theorists may have shown that much harm has been done to society in general, and to colonial societies and developing countries in particular, in the name of presumptive scientific 'Truth'. Nevertheless, we cannot but espouse as a normative ideal the belief that at least some of our scientific beliefs, if formed in the light of the best available evidence, reason, and argument, are capable of truth. And we must acknowledge that the capacity to judge what constitutes the best available scientific evidence is neither evenly distributed nor possessed by democratic decision makers, nor even by democratically constituted decision making bodies. It resides, rather, with experts, and the right kind of experts at that. While these conclusions are unpalatable to many, there is no alternative; or, more accurately, recent South African history has shown that they are more palatable than the alternative.

This was the guiding thought of the second argument: faced with a situation where we know that a misguided health policy has lead to a humanitarian catastrophe, and where postmodernist critique of "Western" science can and has been used to justify this policy, an argument can be made for the preferability of another philosophy of science on which this justification would not have been possible. Death, in medicine, is the kind of epistemic litmus test the existence of which relativists wish to deny: provided other possible causes have been ruled out with sufficient probability, the fact that a given treatment led to a patient's death is enormously good reason to believe not only that the treatment itself is inadequate, but also that the theory used to justify the treatment is probably false. Analogously, the fact that Mbeki's "treatment" led to the avoidable death of hundreds of thousands is enormously good reason to believe not only that it is inadequate, but also that the postmodernist/postcolonialist theory of science he used to justify it is probably false. At the very least, 
and this was the crux, we have enormously good reason to prefer an alternative theory on which this treatment could not be justified.

I closed the paper with the suggestion that it is time for a non-relativist alternative to 20th-century STS, sociology, and postmodernist theory of science. But while recent Studies of Expertise appear promising, it is unlikely that they can deliver it without an epistemology that first returns to its givers their "gift" of epistemic charity. 


\section{Bibliography}

Afshari, R. (1994). "An Essay on Islamic Cultural Relativism in the Discourse of Human Rights." Human Rights Quarterly 16: 235-276.

Allais, L. and W. D. Venter (2012). "HIV, logic and sex in Africa." Prev Med 55(5): 401-404.

Asante, M. (2005). African ways of knowing and cognitive faculties. Encyclopedia of Black Studies. M. K. Asante and A. Mazama. Thousand Oaks, SAGE.

ASSA (2011). Expansion of ARV Programme in SA Slows AIDS Mortality Rate. Cape Town, Actuarial Society of South Africa (ASSA).

Bhabha, H. K. (1992). Postcolonial Criticism. The Transformation of English and American Literary Studies. S. Greenblatt and G. Dunn. New York, Modern Languages Association of America: 437-463.

Butler, A. (2005). "South Africa's HIV/AIDS policy, 1994-2004: How can it be explained?" African Affairs 104(417): 591-614.

Cameron, E. (2005). Witness to AIDS. London New York, I.B. Tauris \& Co Ltd.

Cartwright, J. (2010). "AIDS contrarian ignored warnings of scientific misconduct." Nature Retrieved 08 March 2015.

Castro Hlongwane, Caravans, Cats, Geese, Foot and Mouth Statistics (2002). Virusmyth.com.

Chigwedere, P. and M. Essex (2010). "Aids Denialism and Public Health Practice." AIDS and Behaviour 14: 237-247.

Chigwedere, P., G. R. I. Seage, S. Gruskin, T.-H. Lee and M. Essex (2008). "Estimating the Lost Benefits of Antiretroviral Drug Use in South Africa." Perspectives: Epidemiology and Social Science 49(4): 410-415.

Cohen, J. (1994). "Fulfilling Koch's Postulates." Science 266: 1647.

Collins, H. (2007). "A new programme of research?" Studies in History and Philosophy of Science Part A 38(4): 615-620.

Collins, H. and R. Evans (2007). Rethinking Expertise. Chicago, University of Chicago Press.

Collins, H., M. Weinel and R. Evans (2010). "The politics and policy of the Third Wave: new technologies and society." Critical Policy Studies 4(2): 185-201.

Cullinan, K. and A. Thom (2009). The Virus, Vitamins \& Vegetables. The South African HIV/AIDS Mystery. Auckland Park, Jacana Media.

de Cock, K. M., M. G. Fowler, E. Mercier, I. de Vincenzi, J. Saba, E. Hoff, D. J. Alnwick, M. Rogers and N. Shaffer (2000). "Prevention of Mother-toChild HIV Transmission in Resource-Poor Countries." Journal of the American Medical Association 283(9): 1175-1182. 
Dei, G. J. S. (2004). "Learning culture, spirituality and local knowledge: Implications for African schooling." International Review of Education 48(5): 335-360.

Dennett, D. (1997). Faith in the Truth. Amnesty Lecture, Oxford, February 18, 1997. O. University.

Dennett, D. (2000). Postmodernism and Truth. Twentieth Congress of Philosophy. 8: 93-103.

Dugger, C. W. (2008). Harvard Study Finds Heavy Costs for South Africa's Misguided AIDS Policies. New York Times. New York, New York Times Publishing Co.

Duhem, P. (1906). La Théorie Physique. Son Objet, sa Structure. Paris, Chevalier \& Riviére.

"The Durban Declaration." (2000). Nature 406: 15-16.

Edwards, D., M. Ashmore and J. Potter (1995). "Death and Furniture-the Rhetoric, politics, and theology of bottom line arguments against relativism." History of the Human Sciences 8: 25-49.

Epstein, H. (2000). "The Mystery of AIDS in South Africa." The New York Review of Books 47(12).

Epstein, H. (2007). The Invisible Cure. Africa, the West, and the Fight Against AIDS. London, Viking.

Fassin (2007). When Bodies Remember. Experiences and Politics of AIDS in South Africa. Berkeley, Los Angeles, London, University of California Press.

Fourie, P. and M. Meyer (2010). The Politics of AIDS Denialism. South Africa's Failure to Respond. Surrey, Ashgate Publishing.

Geffen, N. (2010). Debunking Delusions: The Inside Story of the Treatment Action Campaign. Auckland Park, Jacana Media.

Gellman, B. (2000). S. African President Escalates AIDS Feud; Mbeki Challenges Western Remedies. Washington Post. Washington.

Gevisser, M. (2007). The Dream Deferred: Thabo Mbeki. Johannesburg and Cape Town, Jonathan Ball Publishers.

Gumede, W. M. (2007). Thabo Mbeki and the Battle for the Soul of the ANC. London, New York, Zed Books.

Harding, S. (1992). "After Eurocentrism-Challenges for the Philosophy of Science." Philosophy of Science Association 2: 311-319.

Harvey, M. (2000). "How can a virus cause a syndrome, asks Mbeki." Retrieved 12 June 2011, from http://www.aegis.com/news/woza/2000/ IC000906.html.

Hoodbhoy, P. (1991). Islam and Science: Religious Orthodoxy and the Battle for Rationality. London and New Jersey, Zed Books Ltd. 
Horsthemke, K. (2010). "African and Afrikaner ways of knowing: Truth and the problems of superstition and blood knowledge." Theoria 57(123): 2751.

HSRC (2009). South African National HIV Prevalence, Incidence, Behaviour and Communication Survey 2008. H. S. R. Council. Cape Town, Human Sciences Research Council.

Intemann, K. and I. de Melo-Martín (2014). "Are there Limits to Scientists' obligations to Seek and Engage Dissenters?" Synthese 191: 2751-2765.

Jansen, H. (2007). "Refuting a Standpoint by Appealing to Its Outcomes-Reductio ad Absurdum vs. Argument from Consequences." Informal Logic 27(3): 249-266.

Johnson, L. F., J. Mossong, R. E. Dorrington, M. Schomaker, C. J. Hoffmann, O. Keiser, M. P. Fox, R. Wood, H. Prozesky, J. Giddy, D. B. Garone, M. Cornell, M. Egger and A. Boulle (2013). "Life Expectancies of South African Adults Starting Antiretroviral Treatment: Collaborative Analysis of Cohort Studies." PLoS Medicine 10(4).

Jones, W. E. (2002). "Dissident Versus Loyalist: Which Scientists Should We Trust?" Journal of Value Inquiry 36(4): 511-520.

Kalichman, S. (2009). Denying AIDS: Conspiracy Theories, Pseudoscience, and Human Tragedy. New York, Springer.

Kauffman, K. D. (2004). Why is South Africa the HIV Capital of the World? An Institutional Analysis of the Spread of a Virus. AIDS and South Africa: The Social Expression of a Pandemic. K. D. Kauffman and D. Lindauer. New York, Palgrave Macmillan.

Kenyon, C. (2009). "Cognitive dissonance as an explanation of the genesis, evolution and persistence of Thabo Mbeki's HIV denialism." African Journal of AIDS Research 7(1): 29-35.

Kneale, W. and M. Kneale (1962). The Development of Logic. Oxford, Clarendon Press.

Koertge, N., Ed. (1998). A House Built on Sand. Exposing Postmodernist Myths about Science. Oxford, Oxford University Press.

Latour, B. (2004). "Why Has Critique Run out of Steam. From Matters of Fact to Matters of Concern." Critical Inquiry 30: 225-248.

Lloyd, G. (1990). Demystifying Mentalities. Cambridge, Cambridge University Press.

Lodge, T. (2002). Politics in South Africa: From Mandela to Mbeki. Cape Town, New Africa Books.

Longino, H. E. (1994). "In Search of Feminist Epistemology." The Monist 77(4): 472-485.

Maffie, J. (2005). "The Consequences of Ideas." Social Epistemology 19(1): 63-76. 
Marcuse, H. (1955). Eros and Civilization. A Philosophical Inquiry into Freud. Boston, MA, The Beacon Press.

Mbali, M. (2003). HIV/AIDS Policy-Making in Post-Apartheid South Africa. State of the Nation: South Africa 2003-04. J. Daniel and A. Habib. Cape Town, Human Science Research Council Press.

Mbali, M. (2004). "AIDS Discourses and the South African State-Government Denialism and Post-Apartheid AIDS Policy-Making." Transformation 54: 104-122.

Mbeki, T. M. (2000a). Africa's Challenges. An Interview with South African President Thabo Mbeki. T. EUROPE, Time Inc.

Mbeki, T. M. (2000b). Letter to World Leaders.

Mbeki, T. M. (2000c). Sitting down with President Mbeki. Interview on Carte Blanche by Joan Shenton. Carte Blanche. J. Shenton.

Mbeki, T. M. (2005). Address at the Conference of the Association of African Universities, Cape Town, 22 February 2005. Conference of the Association of African Universities, Cape Town, RSA Department of International Relations \& Cooperation.

Mosley, A. (2004). "Does HIV or Poverty Cause AIDS? Biomedical and Epidemiological Perspectives." Theoretical Medicine 25: 399-421.

Mulwo, A. K., K. G. Tomaselli and M. D. Francis (2012). "HIV-AIDS and Discourses of Denial in Sub-Saharan Africa-An Afro-optimist Response?" International Journal of Cultural Studies 15(6): 567-582.

Myburgh, J. (2009). In the Beginning There Was Virodene. The Virus, Vitamns, and Vegetables. The South African HIV/AIDS Mystery. K. Cullinan and A. Thom. Auckland Park, Jacana Media.

Nanda, M. (1998). The Epistemic Charity of the Social Constructivist Critics of Science and Why the Third World Should Refuse the Offer. A House Built on Sand: Exposing Postmodernist Myths about Science. N. Koertge. Oxford, Oxford University Press: 286-311.

Nanda, M. (2003). Prophets Facing Backward. Postmodern Critiques of Science and Hindu Nationalism in India. New Brunswick, New Jersey, and London, Rutgers University Press.

Nattrass, N. (2003). The Moral Economy of AIDS in South Africa. Cambridge, Cambridge University Press.

Nattrass, N. (2007). "AIDS Denialism vs. Science." The Skeptical Inquirer 31(5): 31-37.

Nattrass, N. (2008). "AIDS and the Scientific Governance of Medicine in Post-Apartheid South Africa." African Affairs 107(427): 157-176.

Nattrass, N. (2011). "Defending the boundaries of science: AIDS denialism, peer review and the Medical Hypotheses saga." Sociol Health Illn 33(4): 507-521. 
Nicoll, A. and J. Killewo (2000). "Science, sense, and nonsense about HIV in Africa." Communicable Disease and Public Health 3(2): 78-79.

O'Brien, S. J. and J. J. Goedert (1996). "HIV causes AIDS: Koch postulates fulfilled." Current Opinion in Immunology 8(613-618).

Okin, S. M. (1997). "Is Multiculturalism Bad for Women." Boston Review(October/November).

Phillips, H. (2004). HIV/AIDS in the Context of South Africa's Epidemic History. AIDS and South Africa: the Social Expression of a Pandemic. K. D. Kauffman and D. Lindauer. Basingstoke, Hampshire, Palgrave Macmillan.

Quayson, A. (2000). Postcolonialism: Theory, Practice or Process, Wiley.

Quine, W. v. O. (1951). "Two Dogmas of Empiricism." The Philosophical Review 60(1): 20-43.

Ramatlhodi, N. (2001). Letter to Dr. Makgoba. M. W. Makgoba, New York Times.

Rescher, N. (2005). Reductio ad Absurdum. Internet Encyclopedia of Philosophy.

Said, E. (1978, 2003). Orientalism. London, Penguin Books Ltd.

Schneider, H. and D. Fassin (2002). "Denial and defiance: a socio-political analysis of AIDS in South Africa." AIDS and Behaviour 16: 45-51.

Schuklenk, U. (2004). "Professional responsibilities of biomedical scientists in public discourse." Journal of Medical Ethics 30(1): 53-60.

Sheckels, T. F. (2004). "The Rhetoric of Thabo Mbeki on HIV/AIDS: Strategic Scapegoating?" Howard Journal of Communications 15(2): 69-82.

Sitze, A. (2004). "Denialism." The South Atlantic Quarterly 103(4): 769-811.

Smith, B. H. (1988). Contingencies of Value: Alternative Perspectives for Critical Theory. Cambridge, MA, Harvard University Press.

Thornton, R. (2008). Unimagined Community. Berkeley, University of California Press.

UNAIDS (2010). Global Report. UNAIDS Report on the Global AIDS Epidemic - 2010.

UNAIDS (2012). Treatment 2015. J. U. N. P. o. H. A. (UNAIDS). Geneva, UNAIDS.

van der Vliet, V. (1004). South Africa Divided Against AIDS: A Crisis of Leadership. AIDS and South Africa: the Social Expression of a Pandemic. K. D. Kauffman and D. Lindauer. Basingstoke, Palgrave Macmillan: 48-97.

Weinel, M. (2007). "Primary source knowledge and technical decision-making: Mbeki and the AZT debate." Studies in History and Philosophy of Science Part A 38(4): 748-760. 
Youde, J. (2005). "The Development of a counter-epistemic communicty: AIDS, South Africa, and international regimes." International Relations 19(421-39). 